\section{THE VOLCANOES OF THE TABLE LAND OF MEXICO.}

THE following account with extracts is based on information gathered from a notice which appeared in the Philadelphia Public Ledger, sent us by the courtesy of Prof. Heilprin. He had been obliged to issue the notice in advance of the full publication of his papers by the Academy of Natural Sciences of Philadelphia, as he found on his return many varying reports of the work carried on in Mexico.

Amongst the most recent determinations of the heights of these great volcanoes are those made by the Mexican Expedition lately organized under the auspices of the Academy of Natural Sciences of Philadelphia. Prof. Heilprin has recently placed on record his barometric determinations of the four loftiest summits of the Mexican Republic: Orizaba, Popocatepetl, Ixtaccihuati, and the Nevado de Toluca. In this paper he points out that the highest point of the Republic is the Citlaltepetl or Star Mountain, more commonly called the Peak of Orizaba, and not Popocatepetl as is generally assumed by the Mexican geographers. All his observations were made " with a carefully tested aneroid barometer, and the data were computed from almost simultaneous observations at the Mexican Central Observatory of the City of Mexico, and from barometric readings made at the sea-level at Vera Cruz. The equable condition of the atmosphere, at the time these observations were made, rendered the possibility of the occurrence of possible errors of magnitude almost nil." From the above quotation it will be seen that great care was taken to eliminate all errors and to get as accurate measurements as possible.

Popocatepetl was commonly accepted as the highest peak, and Alexander von Humboldt recorded it in 1804 as 17,720 feet. Since the above date, many trigonometrical surveys have been made, and the results vary from $\mathbf{I} 7,200$ feet to a few feet over 18,000. The latest measurements by Prof. Heilprin give 17,523 feet as the height, being 200 feet lower than Humboldt's estimate. This determination has been derived from the newer data which have been made possible through the levelling of the Mexican Railway, which was constructed a few years since, while geographers have almost universally accepted Humboldt's determinations and figures. From these new data it was shown that "the estimate of the elevation of the city of Mexico (7470 feet), and of the adjoining plateaus, which have served as a basis for most of the angle measurements of the mountains, have been placed 123 feet high. Allowing for this excess, a striking correspondence is established between the early measurements and those obtained in the spring of the year by the Philadelphia Expedition."

Prof. Heilprin and Mr. F. C. Baker made the ascent of this mountain on April 16 and $\mathbf{1 7}$, reaching the "rim of the crater at II.30 o'clock on the morning of the I7th, and the culminating point early in the afternoon of the same day. Little difficulty was encountered in the ascent beyond that which is due to inconvenience arising from the highly rarefied atmosphere. The snow-field was found to be of limited extent, and not more than from five to ten feet in depth, and was virtually absent from the apex of the mountain. The surprisingly mild temperature of the summit, $45^{\circ}$ Fahrenheit, rendered a stay of several hours in cloudland very delightful."

The supposed second highest summit of the Mexican Republic is the mountain of Orizaba or Citlaltepetl, and "the results of Prof. Heilprin's determinations show more marked variations from those of most of the earlier investigators, and more particularly from those of Humboldt." The height determined by Humboldt by means of angles taken from near the town of Galapa, was 17,375 feet, while Ferrer's determination in 1796 gave 1 7,879 feet, as recorded in the Transactions of the American Philosophical Society. The latter value is generally adopted by the German geographers, while the Mexican geographers, on the other hand, adopted the measurement of Humboldt, or "that which was obtained by the National Commissions of I877, indicating a height of 17,664 feet."

The following is a short account of the ascent:- "Prof. Heilprin, with three of his scientific associates and eleven guides, made the ascent on April 6 and 7, or ten days before the ascent of Popocatepetl. The last camp, at a height of some 13,000 feet, was left shortly'before five o'clock in the morning of the second day, and after a difficult and continuous struggle of twelve hours through loose boulders, sand, and a much cut up ice cap, the party-or rather the fragment which succeeded in holding out-finally reached the rim of the crater." At this point, about 120 feet below the apex of the cone, Prof. Heilprin made a measurement which indicated a total height of 18,206 feet, exceeding Ferrers and Humboldt's measures by 325 and 800 feet respectively.

As upon Popocatepetl, "the snow cap, upon Orizaba, although arising 2400 feet, or nearly half a mile above the summit of the highest peak of the Alps, was a comparatively insignificant development." The time spent on the summit was short, lasting only a quarter of an hour, and then followed the descent through the numerous seracs of the ice, which proved most difficult. At a little past eight o'clock in the evening the camp was reached, thus completing "a remarkable round of mountain climbing of fifteen successive hours."

Prof. Heilprin describes the views from the slopes of the mountain as surpassingly grand, exceeding anything that he had seen in his travels. "Far off to the west the giants Popocatepetl and Ixtaccihuatl were clearly outlined against the sky at a distance of about roo miles, while to the east and south the eye wandered over a seemingly endless expanse of plateaus and lowlands, penetrating through a series of successive cloud planes." The measurements of both the peaks of Orizaba and Popocatepetl were made under very similar conditions of the atmosphere; the same instruments were used, and there was only an interval of ten days between the measurements, which points to the conclusion that "the first place among Mexican volcanoes must be accorded to the Star Mountain."

On the 27 th of the same month the ascent of the third highest peak, called the Ixtaccihuatl, was made. The general appearance of this mountain differs considerably from the two mentioned above ; instead of having a symmetrical or conical outline, it has " a strong flowing crest, covered with a heavy deposit, some 75 or roo feet in thickness, of snow and ice, which serves readily to distinguish the familiar "White Woman ' of the plain of Anahuac."

The measurement obtained by Prof. Heilprin of the height of this mountain is 16,962 feet, which height differs by 800 to $\mathbf{1} 300$ feet respectively, from those formerly obtained by the Mexican geographers. Sonntag, in the year 1857, also determined its height, and his result accords very closely (within I I feet) with Prof. Heilprin's. The temperature on the summit was found to be lower than that on either of the other two peaks, the thermometer indicating $32^{\circ} \mathrm{F}$.

In view of the close proximity of this mountain to Popocatepetl, it is difficult " to account for the low value given by Humboldt and the Mexican geographers. So nearly do they appear of equal height that the eye at first fails to distinguish which of the two summits is the higher. German geographers, however, in a few cases, have adopted Sonntag's measurements, neglecting, as in the case of Popocatepetl, to make allowances for the error in this case of 125 feet which is indicated by the levelling of the Mexican Railway."

On April 2, Prof. Heilprin and Mr. Baker ascended the fourth highest summit of the Republic, the Nevado de Toluca. The ascent of this mountain is much easier than the others, and the summit can be reached on horseback to within a distance of 900 feet. The rim of the broken crater " is extremely ragged and narrow, descending with equal abruptness to the inner and outer faces of the volcano. At some points the crest is so attenuated that it can be readily straddled. The height of this mountain was found to be I4,952 feet, which approximately corresponds to the mean between Humboldt's determination and those made by a class of students from the School of Engineers of the city of Toluca.

The results of the measurements of this mountain are very divergent, as will be seen by the following list. La Pérouse, in I786, gave the height as less than 13,000 feet. The British Hydrographic Chart of 1872 gave 14,970 feet, and this estimate is the one which is generally followed by the English and a number of American geographers. Malespina, in 1791, by means of angles taken from positions near Fort Mulgrave, determined the height to be $17,85 x$ feet, while Tebenkoff reduces this figure by about 900 feet.

The most carefully conducted series of measurements are "those which were made by Mr. W. H. Dall, under the auspices of the United States Coast Survey, I874. These yielded results ranging from a little more than $\mathrm{I} 8,000$ to nearly 20,000 feet. The measurements were made from distances 69,127 , and 167 miles, and it is more likely that the discrepancy in the results obtained is due to an uncertainty regarding the actual position of

NO. IO93, VOL. 42] 
the mountain." Even in these latter measurements we bave results in which the extreme variation is about 2000 feet, and this distance compared with 4 miles (about the height of the mountain) is a large quantity, and shows that a still more accurate determination must be made before its height is placed beyond doubt.
From the results of the measurements of the heights of these four mountains, the existing evidence seems to point to the "Star Mountain" of Mexico, the peak of Orizaba, with its 18,200 feet, as the culminating point of the North American continent.

\section{A NEW ELECTRIC LIGHT OTTO GAS-} ENGINE.

F LECTRIC lighting is becoming so universal in all parts at the present day, that we give an illustration of the latest form of gas-engine made by Crossley and Brothers,
Manchester. This engine, called the "High Speed Electric Light Otto Gas-Engine," runs at 250 revolutions, and is designed throughout to run at this exceptional speed. It is fitted with most of the latest improvements, such as Crossley's tube ignition, patent timing valve, and a special electric light governor, which makes it a very steady running engine for this kind of

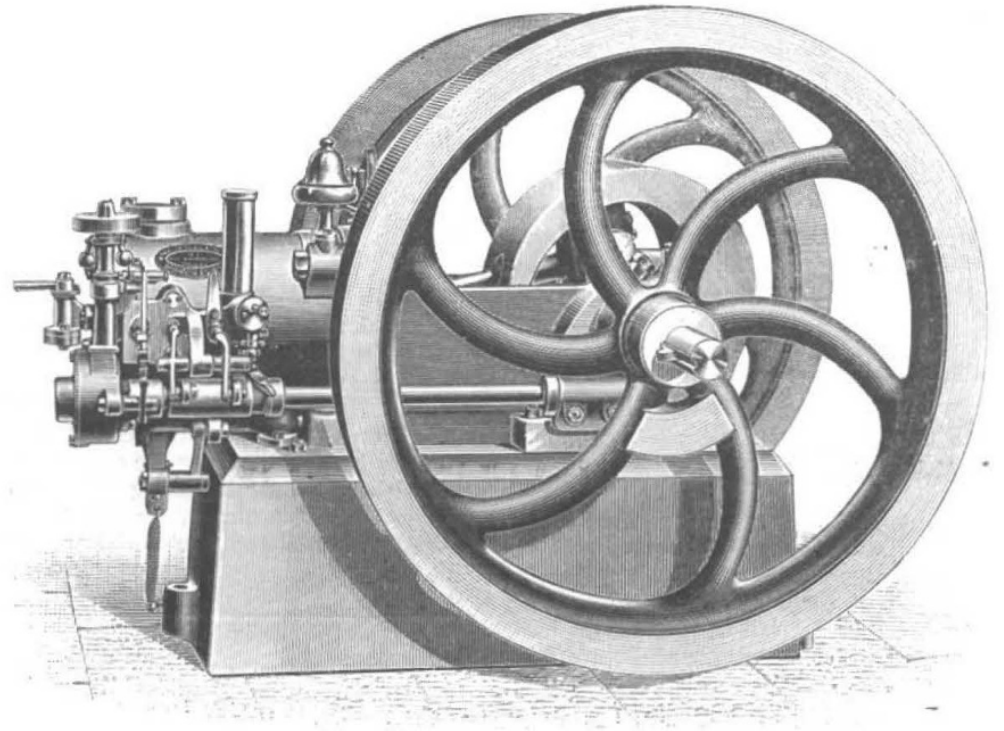

work. The makers claim that "electric light lamps can be driven direct from the dynamo without. fitting the dynamo with a flywheel or disc, as has hitherto been done when a small gas or steam-engine has been used; and that the light will be as absolutely steady as is possible with any form of motive power."

\section{SCIENTIFIC SERIALS.}

THE American Meteorological Fournal for September contains an article, by Prof. H. A. Hazen, on Espy's experiments on storm generation and the liberation of latent heat on cloudformation; these were made about 50 years ago, and Prof, Hazen states that they have never been checked, but have been accepted without question by meteorologists. His own experiments have led to different results, and he finds that deposition from moist air does not set free latent heat.-E. B. Garriott contributes an article on the origin of storms; he attributes their development to an excess of heat from the earth's surface by radiation, and their progressive movement to the precipitation of aqueous vapour at a considerable elevation, while the direction in which they move is regulated by the disposition of cold dry air found in areas of high pressure. For a verification of these facts, he points to the storms of the North American continent, a large majority of which originate over the great plateau region in the lee of the Pacific coast ranges of mountains, and advance towards the regions of greatest moisture which embrace the Great Lakes, the Gulf of Mexico, and the valleys of the principal rivers.-M. Faye has a supplementary article on trombes and tornadoes, for the purpose of introducing the figures illustrating his previous papers in the Tournal. - Mr. M. W. Harrington contributes an instructive paper on forests and soil temperatures. He has taken various sets of observations published in Germany and elsewhere, amounting altogether to I 50 years, and has discussed them by harmonic analysis for various periods, with the view of finding the distribution of temperatures in the soil within and out of the forest, at any depth, and at any time. The greatest difference between the forest soil and that of the open fields is at the surface, the mean difference of forest below open field being about $3^{\circ}$, but below the surface the differences between forest and open field do not progress uniformly. There appears to be a gain of heat in the upper soil of the woods which the open fields do not have.

American Fournal of Mathematics, vol. xiii,, No. I (Baltimore, October 189o). - The opening paper (pp. I-52), entitled " Ueber die zu der Curve $\lambda^{3} \mu+\mu^{3} \nu+\nu^{3} \lambda=0$ im projectiven Sinne gehörende mehrfache Ueberdeckung der Ebene," is by Mellen Woodman Haskell, a name not familiar to us, but belonging evidently to a mathematician of power, The discussion is exhaustive, and is fully illustrated with diagrams in the text, and two large-paged tables containing shaded diagrams. The reader who is familiar with Klein's "Ueber eine neue Art Riemann'scher Flächen" will easily follow the author's work. An index supplies the student with a ready key to the matters handled.-Prof. Cayley (pp. 53-58), in a note on a soluble quintic equation, discusses one of the equations given in Mr. Young's paper, "Soluble Quintic Equations with Commensurable Coefficients" (vol. x. pp. 99-130). The example considered is $x^{5}+3 x^{2}+2 x-1=0$, the solutions of which the author shows admit of being put in much simpler form than those given by Mr. Young.-Then there is an instalment of a course of lectures delivered at the Johns Hopkins University during the months of January and February 1889 , by Oskar Bolza. Its title is "On the Theory of Substitution-groups, and its Applications to Algebraic Equations." The paper is divided into two parts. The first develops the fundamental propositions, and concludes with a

NO. IO93, VOL. 42 ] 